\title{
STUDY OF EFFICIENCY OF ENTERPRISE'S ACTIVITY FROM THE POSITIONS OF CULTURAL CONTENT
}

\author{
Olena Pulianovych \\ Department of Economics \\ Kherson Branch of admiral Makarov National University of Shipbuilding \\ 44 Ushakov ave., Kherson, Ukraine, 73022 \\ lenapul@ukr.net
}

\begin{abstract}
The article describes the main modern approaches to the effectiveness of the enterprise; the concept of a culture of efficiency of the enterprise is proposed; its functions are described, which include integration, socialization, information, regulatory, epistemological and innovative. The content of a culture of efficiency, including complexes of material culture and non-material, external and internal cultures, is determined. It is proved that the management of effectiveness in terms of cultural content depends on a methodical approach to the essence of effectiveness.
\end{abstract}

Keywords: efficiency, methodical approach, culture, functions, content, cultural complex, management.

\section{Introduction}

The development of the enterprise and its long-term activity depends on a culture of business operations, including the relationship to resources. Rational and careful use of resources provides a targeted application of such enterprise positioning tool in the competitive field as efficiency. Efficiency reflects the correlation of results and costs, and with the help of control over investment, constant, variable costs, the enterprise has the opportunity to determine the feasibility of the volumes of their attraction. The importance for understanding the efficiency category and its application as a practical lever for managing processes and their results in the enterprise, as well as the role of efficiency in regulating relations with the external environment can't be overemphasized both at the stage of crisis states and during the period of economic growth. The experience of recent years shows that the struggle for resources that becomes a critical component of competition, not only between enterprises, but also between states. It is access to resources that not only ensures the production capacity, which is related to labor, rhythm of work and even financial results, but also allows the enterprise to be mobile and mobile in making decisions on commodity policy and market behavior.

\section{Literature review and statement of the problem}

The problem of effectiveness is at the center of attention of scientists and practitioners. In the scientific literature it is proposed to consider the effectiveness and the mechanism of its application from the point of view of the action of economic laws that determine the objective measure of costs to obtain a certain volume of wealth [1], and also to investigate the essence and significance of efficiency in production positions [2,3], the authors argue that production itself is the determining sphere for the formation of the cost of production and the efficiency of the enterprise. The production approach to efficiency extends to the knowledge economy, arguing that it is knowledge that provides advantages in the organization and production technologies and determines the efficiency of the enterprise's activity [4]. The concept of efficiency and its essence is of great importance in [5], where the author determines that any managerial decisions should be made taking into account the costs of resources and time.

At the same time, research into the essence of the enterprise's efficiency in both theoretical and practical dimensions doesn't affect its institutional and cultural content, it doesn't allow to determine all possible levers of enterprise performance management and ensure rational use of resources.

A culture of efficiency depends to a large extent on the conceptual vision of efficiency essence. The main epistemological approaches to the essence of efficiency are: from the position of 
the action of economic laws, the production perspective, from the point of view of making managerial decisions, etc.

From the standpoint of the operation of economic laws, efficiency is considered as a category applied in the process of the objective law of saving working time, which reflects the substance of wealth in accordance with the level of costs necessary for its accumulation and use by society. Efficiency and its increase is a concrete form of manifestation of this law [1]. In addition, it can be confirmed that the law of increasing needs is also based on the efficiency category: with the increase in the number and content of needs, there is a need to reduce the time of receipt of funds, objects of their satisfaction. For example, if the delivery time of a good or service to the consumer is greater than it expects, the degree of satisfaction of needs is reduced and the company loses its potential client. This, in turn, can also affect the

The second concept of the effectiveness of the enterprise is the production one. This approach is based on the obsolete production concept of development of the economic entity, according to which the result of the activity is formed mainly in the sphere of production. The efficiency of production is a generalized and complete reflection of the final results of the use of means, objects of labor and labor in the enterprise for a certain period of time, and the overall economic efficiency of production is the overall productivity of the production system [3]. Other scientists correlate the essence of the efficiency of production and the efficiency of the enterprise, determining the problem of increasing the efficiency of production in order to achieve the maximum possible increase in the effect for each unit of current costs and resources; and performance indicators depend mainly on the diversity of the results of the enterprise's activities [2]. There is a point of view that this approach is losing its relevance in the context of expanding the knowledge economy. But the knowledge of production management doesn't lose, but reinforce the value due to their twofold but interrelated nature: on the one hand, for the management of the enterprise an important internal aspect (intra-firm dependencies of subsystems in the cycle of "cost-production-output"); on the other hand, it should also take into account the external aspect in the form of transactions of the "organization" system with its external environment and the corresponding feedbacks [4].

From the point of view of managerial decisions, efficiency is the most common property of any purposeful processes, objectively expressed by the degree of achievement of the goal, taking into account the costs of resources and time. At the same time, the managerial decision is the aggregate effectiveness obtained on the basis of the preparation, development and implementation of the managerial decision and which is defined as the ratio of the result of the decision to the expenses that determine its achievement [5].

\section{The aim and objectives of research}

The aim of this research is to justify the concept of culture of efficiency and the disclosure of its functions and structural content in the enterprise.

To achieve the aim, a critical review of modern approaches to the efficiency category is conducted, philosophical essence and epistemology of culture are defined, and a composite structure of the composition of the effectiveness culture of the enterprise is build.

\section{Materials and methods of research}

In this study, a monographic analysis method was used, which allowed to determine modern approaches to the essence of efficiency; method of causal induction, the use of which allowed to show the dependence of efficiency on its culture; the method of abstraction allowed to form a structural composition of a culture of efficiency.

\section{Research results}

In modern conditions of management, when the human factor plays a major role in formation of the competitiveness of an enterprise, efficiency can't be considered in a break with cultural factors of enterprise management, staff behavior and relationships with the external environment.

The definition of culture of efficiency of enterprise begins with the study of the essence of culture as a philosophical category and a humanitarian phenomenon. The English ethnolo- 
gist E. Taylor, the author of "Primitive Culture" (1871), one of the first to be directly concerned with culture, defines it as an aggregate of knowledge, beliefs, arts, values, laws, customs and other abilities and skills acquired by man as a member of society [6]. In a broad sense, culture is often understood as all created by man, all the achievements of mankind. Culture appears as a "second nature", which is created by the person himself and forms the human world proper, in contrast to the wild nature.

Culture (from Lat. Cultura - cultivation, education, veneration) is a set of extra biological tools and mechanisms of human activity that are necessary for adaptation to the natural environment and the regulation of public life. Culture is inherent in the quality of system, the presence of common sense-building principles, awareness of cultural samples, and symbolic form of their functioning. These features of culture, with all the differences in approaches to it, allow to consider culture as a universal form of human communications: culture is a mechanism for the continuity of various stages in the development of society and the individual, a form of interconnection of various elements of society. Outside of the cultural sphere, interpersonal communication, formation and development of personality are impossible [7].

Culture in content is divided into material and spiritual. Material culture covers the sphere of material production and its products: technics, technology, infrastructure, houses, household items, clothing, etc. Spiritual culture includes the sphere of spiritual production and its results: religion, philosophy, morality, art, science, and so on.

The combination of spiritual and material culture creates a fundamental dimension of human life, determines the mode of existence chosen by mankind. "Culture, obviously, acts as a qualitative aspect of any activity, as a way of thinking and behavior" [8].

Philosophers have proved that the world of culture solves two formally opposite tasks: support of society statics, by preserving and replicating traditions and ensuring its dynamics, thanks to creative innovations. For this, culture creates complex multi-level systems that allow to remove contradictions of the individual and society, old and new, their own and others', normative and situational ones. In this respect, culture can be defined as an information supersystem that provides feedback to the environment while preserving the historical memory stock. At the same time, culture not only encourages and consolidates the qualities necessary for it, but also acts as a repressive force, implements with the help of the system of prohibitions the distinction between "own" and "another's" [9].

Culture is inherent not only to society or to an individual; it acquires an economic character, acts as a factor in increasing the effectiveness of the enterprise. Under the umbrella of culture, any successful enterprise functions. Without cultural factors, it is impossible to implement strategic management and motivate staff to achieve long-term goals.

As part of a culture of the enterprise, a culture of efficiency of its activities occupies a special place as part of the institutional values of management and enterprise development.

Based on the above, a culture of efficiency can determine such state of the enterprise, in which management and personnel carefully treat the resources involved in business; it is in search of innovative, resource-saving technologies, ensure the ecological compatibility of products and their packaging, contribute to a more complete satisfaction of the needs of consumers.

A culture of efficiency performs a wide range of functions defined in Fig. 1.

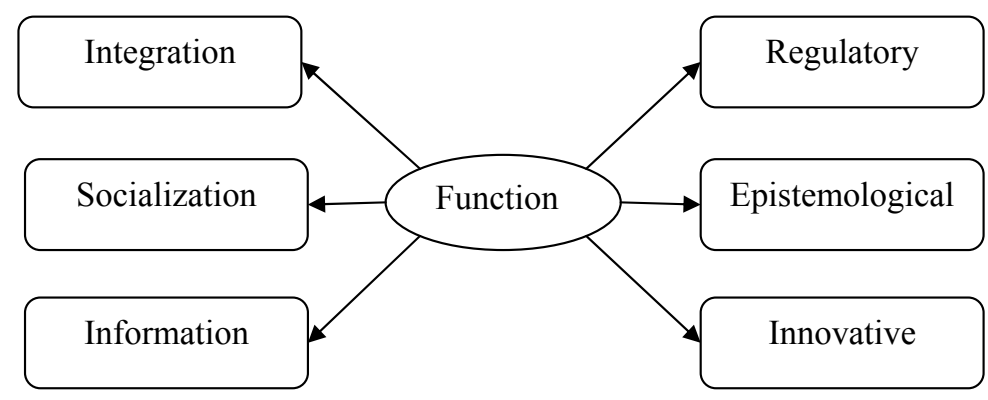

Fig. 1. Functions of a culture of efficiency of enterprise's activity 
1. Integration. A culture of efficiency unites workers of the enterprise around the idea of careful attitude to the environment, helps to form a team of like-minded people, which in turn ensures the achievement of the best results of activity. Joint actions with regard to finding and implementing measures for efficient use of resources provide a synergistic effect, in which the result of the efforts of all team members is greater than the sum of the results of individual actions of individual participants in the business process.

2. Socialization, which is the assimilation of behavior patterns by an employee, psychological attitudes, social norms and values, knowledge, skills that prevail in a collective. Socialization as a function of a culture of efficiency provides, in our opinion, the spread of social responsibility with respect to resources and the achievement of high performance results. Failures in socialization in a culture of efficiency cause "the effect of a white crow", which does not allow a person to feel comfortable and a person either changes place of work or accepts accepted norms of behavior.

3. Information. A culture of efficiency ensures the accumulation of information about modern methods of efficient use of resources, therefore its information function can be aimed at transferring accumulated business experience both "vertically" (from enterprise veterans to young people) and "horizontally" - the exchange of behavioral patterns between individual subgroups in the collective of the enterprise.

4. Regulatory. Equally important is the regulatory function of a culture of efficiency of the enterprise, through which it establishes, organizes and regulates relations between people based on the norms developed at the enterprise. This function is carried out primarily through a system of rules, rules and laws of morality and law, observance of which is a necessary condition for the existence and coexistence of people [10]. In addition, this function contributes to compliance with the labor standards established at the enterprise and the norms for the use of materials, is a prerequisite for the implementation of the enterprise performance strategy.

5. Epistemological. The epistemological function allows to learn the laws of the functioning of the economy, the rules for constructing an effective enterprise, the logic and mechanisms for implementing a cost minimization strategy, etc. Especially important is the realization of the cognitive function of a culture of efficiency, which is embodied in the field of staff development, which must be constant at the enterprise. It is the staff's ability to be adequate to the changes that constantly occur in the external environment and form systemic challenges, is a condition for the enterprise's competitiveness in the long run.

6. Innovative. The innovative function of a culture of efficiency consists of two elements. First, it manifests itself in the ability of the personnel of an enterprise to perceive new elements of technological, organizational and other transformation, thanks to this new forms of management, new technological structures, new organizational systems are created that ensure the self-development of the enterprise and the development of its institutions while maintaining the basic values. Secondly, the innovative function of culture directs participants in economic activities to the development and implementation of innovations that forms the creative potential of the enterprise.

A culture of efficiency, like any culture, consists of elements that can be combined into complexes. This combination depends on the aim of the study and the definition of mechanisms for managing a culture of efficiency.

Cultural complexes constitute the content of culture.

A culture of efficiency can be presented as a unique phenomenon that arises in the sphere of economic activity and contains both complexes of material and non-material culture.

Material culture will include a product created in the course of economic activity, means and objects of labor that are involved in economic activity and provide an effective approach to its implementation.

A culture of efficiency can be internal and external. Due to the fact that the enterprise functions as an open system, the effectiveness of its activities can't be unrelated to the external environment and then forms the so-called external content. So, an enterprise that doesn't take into account the options for recycling packaging by consumers and their cost doesn't actually have a culture of efficiency. 
The internal content of a culture of efficiency is conditioned by business processes occurring within the enterprise and the personnel that participate in it.

A more detailed approach to the composition of a culture of efficiency made it possible to attribute the following to the complexes of a culture of the enterprise's efficiency:

1. Raw materials and materials used in the process of economic activity. The choice of this or that kind of material depends on the strategy of the enterprise, its values, culture and, accordingly, a culture of efficiency. An example of a culture of efficiency is the transition to high-quality substitutes for natural materials, the use of which will destroy nature and worsen the environment.

2. Technical mechanization and deterioration of fixed assets. The older the fixed assets, the less effective they are due to their low productivity, high maintenance costs and non-compliance with modern environmental standards. Therefore, timely updating of fixed assets is a cultural task, the implementation of which ensures more efficient operation of the enterprise.

3. Technological base. The introduction of economical, resource-saving technologies not only provides economic benefits, but also contributes to staff development, modernization of production processes, product sales, and management.

4. Organizational and management resources of the enterprise are a cultural complex that provides not only the formation of values in the enterprise, but also is responsible for their implementation in practice.

5. Moral and ethical values, as a complex of culture of the enterprise's efficiency, cover a range of formal and informal rules of people's behavior based on honesty and responsibility, provide self-control as an important means of avoiding loss of time and materials.

6. Intellectual potential of the enterprise is considered in this work as a complex of a culture of efficiency that covers the capabilities of the enterprise's personnel to manage modern technological processes and the use of appropriate technical means. Today, a technical basis that requires the employee not only to observe or perform working functions, but also to analyze and make decisions, is increasingly applied. The essence of intellectual potential, O. Frolov believes, is displayed as the possibility of a system of intellectual resources (as elements of intellectual capital) to form such managerial competencies that, based on selected business processes, ensure the achievement of certain enterprise strategies [11].

7. The creative potential of the enterprise is defined in this study as a complex of a culture of the efficiency of the enterprise's activity, it is capable to create knowledge, the embodiment of which will contribute to increasing the efficiency of the enterprise's activities.

8. Information resources are a symbiosis of economic and cultural values, which determines their completeness, efficiency and reliability, which in turn ensures the rationality of managerial decisions and the efficiency of the enterprise. The information resources of the enterprise play a special role precisely at enterprises operating in the sphere of the knowledge economy, acting as a resource and as the goal of the enterprise's activity.

Cultural complexes are associated with the realization of certain functions.

Thus, the integration function of a culture of efficiency finds its introduction precisely in complexes of material resources, technologies and technical base.

The function of socialization is manifested more in a complex, which embraces the moral and ethical values of the enterprise.

The information function finds its application mainly in complexes that are responsible for information resources, intellectual, creative and organizational and managerial.

Regulatory function is active in organizational and managerial complex and a complex of moral and ethical values.

The epistemological function covers all cultural complexes of effectiveness: the cognition of reality is the basis of effectiveness. If no resources are found at the enterprise to reduce costs in any field, this causes a decrease in the effectiveness of the activity.

The innovative function also has applications in all cultural complexes, as the generation of new ideas arises in all spheres of the economic and cultural life of the enterprise.

In addition, it is advisable to manage the efficiency of the enterprise's activities from the point of view of its cultural content, taking into account methodological approaches to efficiency. 
So, for example, with the production approach, the emphasis is on activation of the complexes of material culture, and when approaching the management of efficiency from the point of view of making managerial decisions - on the cultural complex of organizational and managerial resources.

\section{Discussion of research results}

The advantage of the article is that it suggests the concept of a culture of efficiency of the enterprise, its functions are revealed and it is proved that the management of effectiveness in terms of cultural content depends on a methodical approach to the essence of efficiency.

In the further research it is planned to investigate and formalize the mechanism of interaction of economic and cultural factors, which provides the competitive advantages of the enterprise.

\section{Conclusions}

A culture of the efficiency of the company's activities is such state of the enterprise's activities, in which management and personnel are carefully treated with the resources attracted to business; they are in search of innovative, resource-saving technologies, ensure the ecological compatibility of products and their packaging, and contribute to a more complete satisfaction of the needs of consumers.

A culture of efficiency performs such functions as integration, socialization, information, regulatory, epistemological and innovative.

A culture of effectiveness is material and intangible culture, both internal and external. A more detailed analysis of the essence of the efficiency culture made it possible to single out the following complexes: materials and raw materials; technologies; technical base; organizational and management resources; moral and ethical values; creative resources; intellectual resources and information resources.

Management of these functions within the cultural content of efficiency will ensure the company's competitive advantages.

\section{References:}

[1] Maniv, Z. O., Luts'kyy, I. M. (2004). Ekonomika pidpryyemstva. Kyiv: Znannya, 580.

[2] Berezin, O. V., Berezina, L.M., Butenko, N. V. (2009). Ekonomika pidpryyemstva. Kyiv: Znannya, 390 .

[3] Boychyk, I. M., Khariv, P.S., Khopchan, M. I. (1998). Ekonomika pidpryyemstva. L'viv: SPOLOM, 212.

[4] Fedulova, L. I. (2009). Ekonomika znan'. Kyiv: NAN Ukrayiny, 600.

[5] Pryymak V.M. (2008). Pryynyattya upravlins'kykh rishen'. Kyiv: Atika, 240.

[6] Tajlor, Je. B. (2003). Pervobytnaja kul'tura. Moscow: Politizdat, 573. Available at: http://www. sati.archaeology.nsc.ru/library/taylor/taylor.html

[7] Kirilenko, G.G., Shevcov, E. V. Filosofija kul'tury. Predstavlenija o kul'ture v istorii filosofskoj mysli. Available at: http://society.polbu.ru/kirilenko_philosophy/ch60_i.html

[8] Soderzhanie i sushhnost' kul'tury. Avilable at: http://moy-bereg.ru/soderzhanie-kulturyi/soderzhanie-i-suschnost-kulturyi.html

[9] Sushhnost' kul'tury, ee struktura i funkcii. Available at: http://studfilosed.ru/lektsii-po-filosofii/534-sushhnost-kultury-ee-struktura-i-funkcii.html

[10] Ponjatie kul'tury, ee sushhnost' i osnovnye funkcii. Available at: http://www.e-reading.me/ chapter.php/39113/154/Mironov___Filosofiya__Uchebnik_dlya_vuzov.html

[11] Frolov, O. O. Intelektual'nyy potentsial ta yoho otsinka na pidpryyemstvi. Available at: http:// www.rusnauka.com/16_ADEN_2011/Economics/10_88465.doc.htm 